\title{
PENGARUH PELAKSANAAN PRAKTEK INDUSTRI (PI) TERHADAP MOTIVASI BELAJAR SISWA KELAS XI IL SMK N 1 WONOASRI
}

\author{
Sulistyaning Kartikawati ${ }^{1}$, Riski Faisal Robianto ${ }^{2}$ \\ ${ }^{1}$ Prodi Pendidikan Teknik Elektro, FPTK, IKIP PGRI Madiun \\ Madiun, 63118, Indonesia \\ ${ }^{2}$ Prodi Pendidikan Teknik Elektro, FPTK, IKIP PGRI Madiun \\ Madiun, 63118, Indonesia \\ Email: Listyosulistyaningkartika@ yahoo.co.id; faisalrobianto@gmail.com
}

\begin{abstract}
ABSTRAK
Praktik Industri merupakan salah satu upaya peningkatan kualitas pendidikan di sekolah kejuruan. Praktik Industri sebagai bagian integral dari pendidikan sistem ganda yang merupakan kegiatan untuk membangun linkand match antara kurikulum SMK dengan dunia industri dan dunia usaha. Pada pelaksanaan kegiatan Praktek Industri siswa memperoleh kesempatan mengaplikasikan secara langsung teori yang mereka peroleh di sekolah pada dunia kerja yang nyata. Pelaksanaan Praktek Industri siswa program keahlian Instalasi Listrik SMK N 1 Wonoasri ditempuh dalam waktu minimal 4 bulan, dilaksanakan pada tingkat XI semester genap. Selama pelaksanaan Praktek Industri tersebut siswa hanya melaksanakan kegiatan di dunia industri, tidak ada kegiatan belajar mengajar di kelas. Hal tersebut tentu saja bisa memberi prngaruh/perubahan pada mental siswa, terutama pada motivasi belajar. Tujuan penelitian ini adalah untuk mengetahui bagaimana pelaksanaan praktek industri sebenarnya di lapangan dan bagaimana pengaruh pelaksanaan Praktek Industri (PI) terhadap motivasi belajar siswa. Diharapkan dari hasil penelitian ini bisa dijadikan sebagai bahan acuan untuk pertimbangan dalam rangka penyempurnaan sistem pelaksanaan Praktek Industri di waktu yang akan datang. Penelitian ini menganalisa temuan - temuan yang diperoleh dari observasi pelaksanaan praktek industri. Hasil penelitian diperoleh dengan cara menghubungkan dua analisa, yaiyu analisa observasi di tempat praktek industri dan analisa motivasi belajar pada setiap siswa praktikan paska pelaksanaan Praktek Industri. Dari kegiatan penelitian ini memperoleh kesimpulan bahwa, Praktek Industri yang dilaksanakan oleh siswa tingkat XI program keahlian Instalasi Listrik SMKN 1 Wonoasri berupa praktek langsung pada dunia kerja yang nyata untuk memperoleh pengalaman yang nyata sesuai dengan program keahlian. Pelaksanaan praktek industri pada setiap dunia usaha, masingmasing mempunyai pengaruh yang berbeda terhadap motivasi belajar siswa, siswa termotivasi belajar lebih baik pada dunia industri yang manajemennya tertata rapi serta mempunyai pembimbing berperan serta aktif.
\end{abstract}

Kata Kunci: PraktekIndustri, MotivasiBelajar

\section{Pendahuluan}

Seiring berkembangnya persaingan global yang semakin pesat, mendorong setiap negara meningkatkan kualitas Sumber Daya Manusia agar mampu bersaing dengan negara - negara lain di dunia. Dalam upaya meningkatkan Sumber Daya Manusia yang berkualitas yang siap menjawab semua tantangan diera globalisasi ini, maka diperlukan sebuah sistem pelaksanaan pendidikan yang berkulitas dan efektif agar pendidikan dapat terarah sesuai tujuan yang diharapkan. Karena pendidikan merupakan faktor yang paling utama dalam menentukan kualitas sumber daya manusia. Dimana kualitas sumber daya manusia adalah faktor penentu kesejahteraan masyarakat dan kemajuan sebuah negara. 
Pendidikan Nasional berfungsi untuk mengembangkan kemampuan dan membentuk watak serta peradaban bangsa yang bermartabat dalam rangka mencerdaskan kehidupan bangsa, berdasarkan fungsi pendidikan nasional tersebut maka pemerintah berupaya meningkatkan efektifitas pendidikan, dan mengatur sistem pendidikan nasional dalam Undang-Undang Sistem Pendidikan Nasional (UUSPN), mengatur Sistem Pendidikan Nasional dari tingkat pendidikan dasar, menengah, sampai pendidikan tinggi.

Undang-Undang Sistem Penddikan Nasional pasal 4 ayat 2 (Kurikulum Sekolah Menengah Kejuruan, 2004: 3) menegaskan pendidikan di Indonesia diselenggarakan sebagai satu kesatuan yang sistematik terbuka dan multimakna. Dalam penjelasan pendidikan terbuka adalah pendidikan yang diselenggarakan dengan fleksibilitas pilihan dan waktu penyelesaian program lintas satuan dan jalur pendidikan (multy entry - multy exit system) siswa dapat belajar sambil bekerja, atau mengambil program pendidikan pada jenis dan jalur pendidikan. Realisasi dari pernyataan tersebut salah satunya adalah adanya Sekolah Menengah Kejuruan (SMK), SMK merupakan pendidikan menengah yang mempersiapkan peserta didik terutama untuk bekerja dalam bidang tertentu.

Depdikbud menegaskan (Wakhiuddin, 2009: 1) upaya pemerintah dalam hal ini Direktorat Menengah dan Kejuruan (Dikmenjur) sebagai upaya mendekatkan pendidikan kejuruan dengan dunia kerja, telah dilakukan dengan adanya kebijakan link and match. Sebagai realisasi dari kebijakan tersebut, maka telah dicanangkan konsep pendidikan dengan sistem ganda (PSG). Pendidikan Sistem Ganda adalah bentuk penyelenggaraan pendidikan yang memadukan pendidikan sekolah dengan penguasaan keahlian yang diperoleh melalui kegiatan bekerja langsung di dunia kerja. Realisasi dari Pendidikan Sistem Ganda tersebut adalah dilasanakannya praktek kerja industri (Prakerin) atau Praktek industri.

Praktek Industri adalah kegiatan praktek bekerja di lapangan atau dunia industri. Pada pelaksanaan kegiatan Praktek Industri (PI) siswa memperoleh kesempatan mengaplikasikan secara langsung teori yang mereka peroleh di sekolah pada dunia kerja yang nyata. Harapan dari pelaksanaan Praktek Industri ini memberikan pengalaman yang baru kepada siswa yaitu pengalaman bekerja di dunia industri, dimana pengalaman tersebut belum mereka dapatkan ketika belajar di kelas, praktek di laboratorium atau bengkel sekolah, mengingat pengalaman adalah bagian dari proses pendidikan, serta guru yang paling berharga.

Praktek Industri di SMK N 1 Wonoasri ditempuh dalam waktu minimal 4 bulan, dilaksanakan siswa tingkat XI semester genap, atau menyesuaikan jurusan masing - masing. Dimana selama pelaksanaan Praktek Industri siswa hanya melaksanakan kegiatan di dunia industri, tidak ada kegiatan belajar mengajar di kelas, praktek di laboratorium maupun di bengkel sekolah. Siswa aktif dalam kegiatan Praktek Industri (PI) di dunia industri/dunia kerja, mereka mencari dan mendapatkan pengalaman secara langsung di dunia industri/dunia kerja yang nyata, akan tetapi siswa vakum dalam kegiatan belajar terutama pada mata pelajaran adaptif (Ilmu Pengetahuan Dasar Penunjang) dan normatif (Ilmu Pengetahuan Umum), karena selama pelaksanaan praktek industri tersebut siswa tidak mendapatkan pelajaran di kelas.

Kegiatan pelaksanaan praktek industri tersebut tentu saja bisa memberi perubahan pada mental siswa, terutama pada motivasi belajar. Oleh karena itu perlu adanya sebuah penelitian untuk mengetahui bagaimana pengaruh pelaksanaan Praktek Industri (PI) terhadap mental siswa terutama pada motivasi belajarnya. Sehingga diharapkan dari hasil penelitian tersebut bisa dijadikan sebagai bahan 
acuan untuk pertimbangan dalam rangka penyempurnaan sistem pelaksanaan Praktek Industri di waktu yang akan datang.

Berdasarkan identifikasi pemasalahan yang telah di uraikan sebelumnya maka Tujuan dari penelitian ini antara lain;

1. Untuk mengetahui situasi dan kondisi Pelaksanaan Praktek Industri secara langsung.

2. Untuk mengetahui bagaimana pengaruh pelaksanaan Praktek Industri terhadap motivasi belajar siswa.

\section{Metode}

Penelitian ini dilaksanakan pada kelas XI IL 1 dan XI IL 2 di SMK Negeri 1 Wonoasri yang beralamat di Jalan Panglima Sudirman No. 1 Purwosari, Caruban. Jenis penelitian ini adalah deskriptif analitik, data yang di peroleh (berupa kata-kata, gambar, perilaku) tidak dituangkan dalam bentuk bilangan atau angka statistik, melainkan tetap dalam bentuk kualitatif yang memiliki arti lebih kaya dari sekedar angka dan frekuensi (Margono, 2004: 39 ).

Penelitian ini menganalisa temuantemuan yang diperoleh dari observasi pelaksanaan praktek industri di lapangan dan selain itu juga ada penelitian terhadap motivasi belajar siswa paska pelaksanaan praktek industri. Hasil penelitian diperoleh dengan cara menghubungkan dua analisa, yaitu analisa observasi di tempat praktek industri dan analisa motivasi belajar pada setiap siswa praktikan paska pelaksanaan Praktek Industri. Dari observasi pelaksanaan praktek industri di lapangan peneliti mengumpulkan data berupa kuisioner yang diisi oleh pembimbing siswa praktikan/pihak industri, peneliti juga memperoleh data berupa gambaran langsung pelaksanaan praktek industri di lapangan.

Selain observasi di tempat Praktek Industri peneliti juga mengadakan penelitian untuk mendapatkan data motivasi belajar siswa setelah kembali dari pelaksanaan praktek industri. Penelitian dilakukan dengan menggunakan kuisioner tertutup. Dalam penelitian ini data yang diperlukan adalah informasi tentang gambaran secara nyata pelaksanaan Praktek Industri di lapangan dan data motivasi belajar siswa paska pelaksanaan Praktek Industri.

Pada penelitian ini terlebih dahulu peneliti mencari informasi serta gambaran yang sesungguhnya pelaksanaan praktek industri di lapangan dengan cara mengadakan observasi dan pengamatan langsung ke lapangan tempat siswa kelas XI IL SMK Negeri 1 Wonoasri melaksanakan Praktek Industri. Dalam observasi dan pengamatan tersebut peneliti juga memberikan kuisioner kepada pembimbing siswa praktikan di tempat Praktek Industri yang tujuannya untuk memperoleh data yang lebih lengkap dan akurat.

Setelah mendapatkan data dan informasi dalam pelaksanaan Praktek Industri di lapangan, peneliti juga mengamati motivasi belajar pada setiap siswa setelah kembali ke sekolah untuk melaksanakan kegiatan belajar mengajar.

Dari pengamatan yang laksanakan di lapangan dan di sekolah tersebut sehingga peneliti mempunyai 2 kelompok data. Peneliti menghubungan 2 kelompok data tersebut dan menganalisa sehingga diperoleh hasil penelitian yang berupa paparan data dan kesimpulan-kesimpulan.

Analisis data dilakukan setelah data yang di peroleh terkumpul, dalam penelitian ini terkumpul data observasi dan data kuisioner yang di isi oleh pembimbing di dunia industri dan dari kuisioner yang diisi oleh siswa praktikan.

Pada penelitian ini ada 3 proses analisa, analisa yang pertama bertujuan untuk menganalisa hasil observasi, yang kedua adalah analisa data dari hasil tes kuisioner siswa praktikan. Dan analisa yang terakhir adalah analisa untuk menggabungkan 2 data yang diperoleh dari analisa sebelumnya.

\section{Hasil}


Peneliti mengunjungi beberapa tempat praktek industri yang dipilih sebagai sampel untuk melakukan observasi dan dokumentasi. Observasi praktek industri dilaksanakan tanggal 21-31 maret 2015. Dari hasil observasi serta dokumentasi peneliti pada tempat pelaksanaan praktek industri dapat diuraikan sebagai berikut:

\section{Praktek Industri di PT. Nusantara Surya Gemilang}

PT. Nusantara Surya Gemilang adalah perusahanaan yang bergerak dibidang kontraktor listrik. Perusahaan ini beralamat di J1. Margobawero No 65 Kota Madiun. PT. Nusantara Surya Gemilang termasuk perusahaan di bawah PT. PLN (persero) yang melaksanakan beberapa proyek PLN.

Pekerjaan praktek yang dilakukan olek siswa praktikan di PT. Nusantara Surya Gemilang adalah sebagai berikut

a. Memasang instalasi listrik rumah tinggal

b. Pemasangan baru listrik PLN

c. Pemasangan jaringan (JTM/JTR)

d. Bongkar dan pasang transformator.

e. Pemeliharaan jaringan distribusi PLN

PT. Nusantara Surya Gemilang mempunyai sistem Manajemen yang bagus. Di sini siswa praktikan selalu diberi pengarahan berupa tata cara, sistem dan aturan kerja agar pekerjaan yang siswa praktikan kerjakan sesuai dengan SOP .Siswa praktikan di sini dibimbing oleh Bapak Budi Harsono, beliau adalah salah seorang karyawan di PT. Nusantara Surya Gemilang.

2. Praktek Industri di PLN ( Persero ) APJ Madiun

PLN APJ Madiun berada di alamat jalan Letjend Haryono no 30 kota Madiun. Pelaksana lapangan di PLN ( Persero ) APJ Madiun diserahkan oleh pihak outsoursing yaitu PT.APP, sehingga praktek industri siswa praktikan di sini dilaksanakan bersama karyawan PT.APP. Tugas dari PT.APP adalah perawatan jaringan rayon kota
Madiun, dan pelayanan teknik terhadap konsumen PLN.

Pembimbing siswa praktikan disini adalah bapak Didik Sumarsono, beliau adalah salah satu karyawan PT.APP yang di tempatkan pada bagian perlayanan teknik, dan perawatan jaringan di PLN APJ Madiun.

Berikut adalah pekerjaan yang dilaksanakan siswa praktikan selama melaksanakan praktek industri di PLN APJ Madiun;

a. Memelihara/pengecekan panel/transformator.

b. Mengukur dengan menggunakan EMT dan Tang Ampere.

c. Pemeliharaan jaringan/pembersihan dahan pohon yang dapat menggangu jaringan.

d. Pelayanan teknis pada gangguan jaringan.

Dalam pelaksanaan kegiatan praktek kerja disini siswa selalu diberi pengarahan dan bimbingan dari pembimbing sebelum melaksanankan pekerjaan, Selain itu pembimbing juga selalu memberikan evaluasi pada siswa praktikan setiap akhir kegiatan praktek kerja.

Siswa praktikan di PLN (Persero) APJ Madiun harus bekerja dengan sungguh - sungguh selalu bekerja sesuai dengan SOP, mengikuti peraturan tata tertib yang berlaku padaperusahaan termasuk datang dan pulang sesuai dengan aturan perusahaan. Manajemen yang bagus dari perusahaan ini menuntuk siswa yang melaksanakan Praktek Industri disini untuk selalu disiplin setiap waktu. Dan apabila ada siswa praktikan yang melanggar tata tertib yang ditentukan oleh perusahaan maka pihak perusahaan akan membereri sanksi berupa teguran dan arahan kepada siswa praktikan.

3. Praktek Industri di Servis Dinamo Yono Caruban

Servis Dinamo Yono beralamat di jalan Ahmad Yani no 58 Caruban, 
sesuai dengan nama Servis Dinamo Yono, nama pemiliknya adalah Supriyono. Bapak Supriyono belum mempunyai karyawan, jadi bapak Supriyono pemilik sekaligus tenaga ahli di bengkelnya.

Bengkel bapak Supriyono menerima servis atau berbaikan berbagai macam dinamo atau motor listrik, berikut adalah pekerjaan siswa praktikan yang dilaksanakan di bengkel pak Supriyono.

a. Membongkar dan memasang dinamo atau motor listrik yang rusak.

b. Membantu

memperbaiki/menggulung dinamo atau motor listrik.

Selain memberi pengalaman kepada siswa praktikan berupa ketrampilan memperbaiki dinamo atau motor listrik, bapak Supriyono juga memberikan pengarahan agar siswa praktikan bisa saling kerjasama dalam melaksanakan pekerjaan.

Tidak ada peraturan yang dibuat tertulis kepada siswa praktikan disini, akan tetapi bapak Supriono selalu mengingatkan kepada siswa praktikan agar selalu merapikan tempat kerja setelah selesai bekerja dan selalu datang dan pulang tepat waktu. Dalam suatu kunjungan observasi, peneliti tidak menemukan siswa praktikan di tempat kerja, namun pembimbing beralasan siswa masih diperintah pembimbing untuk membeli bahan/peralatan.

4. Praktek Industri di CV. Cahaya Firdaus Dhevano

CV. Cahaya Firdaus Dhevano berkantor di jalan Rajawali 30A Batungampel, Caruban. Bapak Suryadi ST adalah nama pemilik dan sekaligus sebagai pemimpin di perusahaan ini. CV. Cahaya Firdaus Dhevano adalah perusahaan yang bergerak dibidang biro pelayanan teknik terhadap pelanggan PLN terutama untuk pemasangan baru pelanggan, Instalasi Listrik dan pembayaran rekening listrik secara online.
Perusahaan ini memiliki karyawan kurang dari lima orang, satu sekretaris dan dua orang karyawan yang bertugas di lapangan. Siswa praktikan di sini berkesempatan mendapatkan pengalaman di lapangan dan bekerja di kantor. Bapak Suryadi,ST juga menjadi pembimbing siswa praktikan di perusahaan ini.

Berikut adalah pekerjaan yang dilaksanakan siswa praktikan selama melaksanakan praktek industri di CV. Cahaya Firdaus Dhevano;

a. Menyusun dan memasang instalasi Listrik rumah tangga.

b. Menyambung (Sambungan Rumah) pelanggan baru PLN (memasang KWH meter)

c. Perbaikan pada kerusakan instalasi listrik rumah tangga.

d. Melayani pembayaran listrik pelanggan PLN

Selain mendapatkan ketrampilan secara teknik, siswa praktikan juga berkesempatan mendapatkan pengalaman tata cara pembayaran listrik secara online. Siswa praktikan di sini juga diajari cara deposit pembayaran listrik, sehingga mereka mempunyai bekal ilmu dan pengalaman untuk mejadi seorang wiraswasta.

\section{Praktek Industri di Servis Dinamo Pak Pur Dumpil}

Servis Dinamo Pak Pur Dumpil adalah bengkel yang melayani perbaikan kerusakan mesin listrik. Bengkel ini mampu memperbaiki kerusakan mesin listrik pompa air (SANYO) sampai dinamo ampere pada mesin kendaraan bermotor (mobil dan Truk), baik kerusakan ringan maupun gulung ulang kumparan mesin listrik.

Bengkel ini terletak di desa Garon, kecamatan Balerejo kabupaten Madiun. Sesuai dengan nama bengkel, nama pemilik usaha ini adalah bapak Purwanto, biasa dipanggil pak Pur oleh pelanggannya. Bengkel ini tidak memiliki karyawan. Oleh sebab itu Bapak Purwanto lah yang jadi 
pembimbing siswa praktikan di bengkel ini.

Sedikit pengalaman yang diperoleh para siswa praktikan dibengkel ini akan tetapi pengalaman tersebut sangat berharga, karena hanya sedikit orang yang punya pengalaman di bengkel mesin listrik. Berikut ini adalah pekerjaan praktek indutri yang mereka kerjakan di bengkel ini.

a. Membongkar dan memasang dinamo ampere pada kendaraan (mobil dan truk)

b. Memeriksa kerusakan pada mesin listrik.

c. Membongkar dan gulung ulang kumparan mesin listrik.

Tidak ada peraturan tertulis secara khusus yang diberikan kepada siswa praktikan dibengkel ini, berdasarkan dari isi kuisioner yang diisi oleh bapak Purwanto, siswa praktikan harus rajin dan giat dalam bekerja. Tetapi waktu pertama kali peneliti mengadakan observasi di bengkel, tidak ada siswa praktikan yang masuk.

\section{Praktek Industri di Rama Teknik}

Bengkel Rama teknik adalah bengkel yang melayani perbaikan peralatan listrik rumah tangga, baik mesin penggerak, pendingin maupun pemanas. Bengkel ini juga siap menerima panggilan untuk datang ke rumah pelanggannya. Rama Teknik beralamat di jalan Ahmad Yani No.62 Caruban, Madiun, tepatnya di depan gedung DPRD Kabupaten Madiun.

Bapak Sadimun Saputro adalah pemilik dan sekaligus pemimpin di bengkel ini. Bengkel ini mempunyai dua orang karyawan, akan tetapi bapak Sadimun membimbing sendiri siswa praktikan di bengkel ini.

Di bengkel ini setiap hari buka kecuali hari jum'at, siswa praktikan masuk sesuai ketentuan hari masuk tersebut, mulai jam 8 pagi sampai jam 4 sore. Banyak pengalaman yang diperoleh siswa praktikan di bengkel ini, berikut adalah pekerjaan praktek yang dikerjakan siswa praktikan disini; a. Memperbaiki kipas angin dan motor pompa air.

b. Memperbaiki Ricecooker dan magic jar

c. Memperbaiki kulkas dan AC

d. Memperbaiki mesin cuci

Selain memberi pengalaman kepada siswa praktikan berupa ketrampilan memberbaiki beberapa peralatan listrik, bapak Sadimun juga menanamkan sikap tanggung jawab yang penuh kepada siswa praktikan disini. Dalam dua kali kunjungan di sini, observasi yang pertama, peneliti menemukan siswa yang sedang bekerja membongkar motor listrik pendingin $\mathrm{AC}$, padahal pemilik bengkel dan karyawannya sedang mendapat panggilan bekerja di rumah pelanggan.

\section{Pembahasan}

Penelitian ini bersifat kualitatif maka pembahasan pada penelitian ini berupa deskripsi dari peneliti untuk menjawab identifikasi masalah yang telah disampaikan sebelumnya.

\section{Pelaksanaan Praktek Industri SMKN 1 Wonoasri}

Sesuai kesimpulan yang telah disampaikan sebelumnya, Praktek Industri adalah kegiatan pendidikan, pelatihan, dan pembelajaran yang dilakukan oleh peserta didik sekolah mengengah kejuruan berupa praktek langsung pada dunia kerja yang nyata untuk memperoleh pengalaman yang nyata sesuai dengan program keahlian guna meningkatkan keahlian yang profesional dibidangnya.

Praktek Indistri oleh siswa SMKN 1 Wonoasri dilaksanakan secara nyata di berbagai tempat, dunia usaha/industri. Sesuai dengan teori yang telah disajikan, siswa SMKN 1 Wonoasri praktek bekerja secara nyata pada dunia usaha/industri untuk mendapatkan pengalaman yang nyata.

Praktek industri siswa SMKN 1 Wonoasri dilaksanakan di berbagai tempat, mulai dari bengkel kecil sampai perusahaan sekelas PLN. Bengkel/perusahaan tersebut mempunyai bidang usaha yang berbeda, namun 
pekerjaan yang dipraktekan oleh siswa praktikan tidak menyimpang dengan program bidang keahliannya.

\section{Pengaruh Pelaksanaan Praktek Industri terhadap Motivasi Belajar}

Setiap tempat usaha/industri yang digunakan sebagai tempat untuk melaksanakan tempat praktek industri mempunyai karakter tersendiri, mempunyai keunggulan dan kelemahan masing - masing yang berbeda. Pada pembahasan ini peneliti akan menguraikannya dan menghubungkan dengan motivasi belajar. Motivasi belajar yang telah peneliti ujikan kepada siswa SMKN 1 Wonoasri kelas XI IL 1 dan XI IL 2.

\section{Nusantara Surya Gemilang.}

PT. Nusantara Surya Gemilang mempunyai manajemen yang tertata baik, sehingga setiap karyawan disini harus selalu mematuhi peraturan dan SOP (Standart Operating Procedures) yang telah ada, begitu pula dengan siswa praktikan. Dari sini peneliti menyimpulkan bahwa siswa pratikan disini dipupuk rasa tanggungjawab dan kedisiplinannya.

Deskripsi Nilai Motivasi rata - rata belajar siswa praktikan disini masuk dalam kategori baik, berikut utaian datanya;

Tabel 1. Deskripsi Nilai Motivasi Belajar rata - rata siswa praktikan di PT. Nusantara Surya Gemilang.

\begin{tabular}{|c|c|c|c|}
\hline No & Nama Siswa & $\begin{array}{c}\text { Nilai } \\
\text { Motivasi } \\
\text { Belajar }\end{array}$ & $\begin{array}{c}\text { Rerata } \\
\text { Motivasi } \\
\text { Belajar }\end{array}$ \\
\hline 1 & $\begin{array}{l}\text { Fuad } \\
\text { Firmansyah }\end{array}$ & 79.33 & \\
\hline 2 & Nur Afandi & 64 & \\
\hline 3 & $\begin{array}{l}\text { M. Riski Nur } \\
\text { A }\end{array}$ & 70.67 & 71 \\
\hline 4 & $\begin{array}{l}\text { Setyan Bayu } \\
\text { C }\end{array}$ & 70 & \\
\hline
\end{tabular}

\section{PLN APJ Kota Madiun.}

PLN termasuk perusahaan yang besar, manajemen perusahaan ini tertata dengan baik, siswa praktikan disini bekerja bersama karyawan dari PT.APP. pembimbing praktek industri disini pembimbing selalu memberikan arahan sebelum mulai bekerja dan evaluasi pada siswa praktikan setiap akhir kegiatan kerja.

Deskripsi Nilai Motivasi belajar rata rata siswa praktikan disini adalah yang terttinggi dari enam tempat praktek industri yang kami jadikan sampel, berikut utaian datanya;

Tabel 2. Deskripsi Nilai Motivasi Belajar rata - rata siswa praktikan di PLN APJ Kota Madiun.

\begin{tabular}{clcc}
\hline No & NamaSiswa & $\begin{array}{c}\text { Nilai } \\
\text { Motivasi } \\
\text { Belajar }\end{array}$ & $\begin{array}{c}\text { Rerata } \\
\text { Nilai } \\
\text { Motivasi } \\
\text { Belajar }\end{array}$ \\
\cline { 1 - 2 } 1 & $\begin{array}{l}\text { Dodik Ismail } \\
\text { Marzuki }\end{array}$ & 77.33 & \\
\cline { 1 - 2 } 2 & $\begin{array}{l}\text { Tomy } \\
\text { Prasetyo }\end{array}$ & 76 & \\
\hline 3 & Nur Wahyudi & 82 & \\
\hline 4 & $\begin{array}{l}\text { Puguh } \\
\text { Harianto }\end{array}$ & 80 & \\
\cline { 1 - 2 } 5 & $\begin{array}{l}\text { Romadhon } \\
\text { Ernanto }\end{array}$ & 87.33 & \\
\hline
\end{tabular}

\section{Servis Dinamo Yono Caruban}

Servis dinamo Yono adalah sebuah bengkel reparasi yang berada di jalan Ahmad Yani, Caruban. Banyak pengalaman berharga yang diperoleh siswa praktikan di sini, karena kemampuan untuk memperbaiki peralatan motor listrik sangat langka dimiliki orang. Namun pada waktu kunjungan peneliti untuk melakukan observasi menemukan siswa praktikan tidak berada di tempat pada saat jam kerja.

Deskripsi Nilai Motivasi belajar rata rata siswa praktikan di sini mendapat nilai yang paling rendah dari enam sampel yang peneliti kunjungi.

Tabel 3. Deskripsi Nilai Motivasi Belajar rata-rata siswa praktikan di Servis dinamo Yono.

\begin{tabular}{cccc}
\hline No & Nama Siswa & $\begin{array}{c}\text { Nilai } \\
\text { Motivasi } \\
\text { Belajar }\end{array}$ & $\begin{array}{c}\text { Rerata } \\
\text { Nilai } \\
\text { Motivasi } \\
\text { Belajar }\end{array}$ \\
\cline { 1 - 2 } 1 & Pengky Fiim A & 53.33 & 62 \\
\cline { 1 - 2 } 2 & Alifa Bagus S & 70.67 & \\
\hline
\end{tabular}




\section{CV. Cahaya Firdaus Dhevano.}

CV. Cahaya Firdaus Dhevano adalah usaha yang bergerak dibidang biro instalatir listrik rumah tangga. Selain mendapatkan ketrampilan teknik instalasi listrik, siswa praktikan di CV. Cahaya Firdaus Dhevano berkesempatan mendapatkan pengalaman tata cara pembayaran listrik secara online. Siswa praktikan di sini juga diajari cara deposit pembayaran listrik, sehingga mereka mempunyai bekal ilmu dan pengalaman untuk mejadi seorang wiraswasta.

Deskripsi Nilai Motivasi Belajar rata rata siswa praktikan di sini mendapat urutan yang kedua tertinggi, dari enam sampel tempat yang kami kunjungi untuk diobservasi.

Tabel 4. Deskripsi Nilai Motivasi Belajar rata-rata siswa praktikan di CV. Cahaya Firdaus Dhevano.

\begin{tabular}{|c|c|c|c|}
\hline No & NamaSiswa & $\begin{array}{l}\text { NilaiM } \\
\text { otivasi }\end{array}$ & $\begin{array}{l}\text { Rerata } \\
\text { NilaiM } \\
\text { otivasi }\end{array}$ \\
\hline 1 & WahyudiPradana & 78.67 & \multirow{6}{*}{73,34} \\
\hline 2 & YoyokWicaksono & 74.67 & \\
\hline 3 & AndikWiyono & 72.67 & \\
\hline 4 & DidikPurnomo & 70 & \\
\hline 5 & $\begin{array}{l}\text { PramudyaRendy } \\
\text { P }\end{array}$ & 64.67 & \\
\hline 6 & SugengRiyanto & 79.33 & \\
\hline
\end{tabular}

\section{Servis Dinamo Pak Pur Dumpil}

Seperti di bengkel dinamo Yono, di bengkel Servis Dinamo Pak Pur Dumpil peneliti menemukan siswa praktikan tidak berada pada tempat pada waktu jam kerja, namun pembimbing mengatakan emang hari ini libur. Kunjungan observasi yang kedua peneliti melihat pembimbing masih sibuk bekerja sendirian, sedangkan siswa praktikan duduk mendengankan radio.

Deskripsi Nilai Motivasi Belajar rata rata siswa praktikan disini adalah yang paling rendah nomor dua, dari enam sampel yang kami kunungi untuk observasi.
Tabel 5. Deskripsi Nilai Motivasi Belajar rata-rata siswa praktikan di Servis Dinamo Pak Pur Dumpil.

\begin{tabular}{clcc}
\hline No & $\begin{array}{l}\text { Nama } \\
\text { Siswa }\end{array}$ & $\begin{array}{c}\text { Deskripsi } \\
\text { Nilai Motivasi }\end{array}$ & $\begin{array}{c}\text { Deskripsi } \\
\text { Nilai Motivasi } \\
\text { rata-rata }\end{array}$ \\
\cline { 1 - 2 } 1 & $\begin{array}{l}\text { Nanang } \\
\text { Eko } \\
\text { Saputro }\end{array}$ & Absen & \\
\cline { 1 - 2 } 2 & $\begin{array}{l}\text { Heru } \\
\text { Prianto }\end{array}$ & \multirow{2}{*}{58.67} & \\
\cline { 2 - 2 } 3 & $\begin{array}{l}\text { Riki } \\
\text { Armada }\end{array}$ & 61.36 \\
\cline { 1 - 2 } 4 & $\begin{array}{l}\text { Udiek } \\
\text { Rudi O }\end{array}$ & 70.67 & \\
\hline 6
\end{tabular}

\section{Rama Teknik}

Selain memberi pengalaman kepada siswa praktikan berupa ketrampilan memberbaiki beberapa peralatan listrik, pembimbing di sisni juga menanamkan sikap tanggung jawab yang penuh kepada siswa praktikan disini. Dalam dua kali kunjungan disini, observasi yang pertama, peneliti menemukan siswa yang sedang bekerja membongkar motor listrik pendingin AC, padahal pemilik dan karyawan bengkel sedang mendapat panggilan untuk perbaikan $\mathrm{AC}$ di rumah pelanggan.

Tabel 6. Deskripsi Nilai Motivasi Belajar rata-rata siswa praktikan di bengkel Rama Teknik.

\begin{tabular}{clcc}
\hline No & NamaSiswa & $\begin{array}{c}\text { Nilai } \\
\text { Motivasi }\end{array}$ & $\begin{array}{c}\text { Rerata } \\
\text { Nilai } \\
\text { Motivasi }\end{array}$ \\
\cline { 1 - 2 } 1 & $\begin{array}{l}\text { Bayu } \\
\text { Pratama }\end{array}$ & 74 & 73 \\
\cline { 1 - 2 } 2 & $\begin{array}{l}\text { Bima Reziandi } \\
\text { Cahyo }\end{array}$ & 72 & \\
\hline
\end{tabular}

\section{Kesimpulan}

Berdasarkan hasil analisa data yang terdapat pada paparan data dan pembahasan masalah yang telah disampaikan sebelumnya, maka peneliti dapat mengambil kesimpulan sebagai berikut:

1. Praktek industri yang dilaksanakan oleh siswa tingkat XI IL 1 dan XI IL 2 SMKN 1 Wonoasri berupa praktek langsung pada dunia kerja yang nyata 
untuk memperoleh pengalaman yang nyata sesuai dengan program keahlian

2. Pelaksanaan praktek industry pada setiap dunia usaha, masing-masing mempunyai pengaruh yang berbeda terhadap motivasi belajar siswa, siswa termotivasi belajar lebih baik pada dunia industri yang manajemennya tertata rapi serta mempunyai pembimbing berperan serta aktif.

\section{Daftar Pustaka}

Aunnrrahman. 2009. Belajar dan Pembelajaran. Bandung; Alfabeta.

Dimyati dan Mudjiono .2009 . Belajar dan pembelajaran.

Jakarta; PT.Rineka cipta.

Direktorat Jenderal Pendidikan Menengah Kejuruan. 2004. Kurikulum Sekolah Menengah Kejuruan, Landasan, Program, dan Pegembangan. Departemen Pendidikan Nasional

Hamzah B. Uno. 2007. Teori Motivasi dan Pengukurannya. Jakarta; Bumi Aksara.

Made Wena. 1996. Pendidikan Sistem Ganda, Pendidikan Kejuruan.Bandung; Tarsito.

Muhamad Nur. 2001. Pemotivasian Siswa Untuk Belajar. Surabaya; Universitas Negeri Surabaya, Pusat Saint dan Matematika Sekolah.

Nolker Helmut dan Schoenfeldt Eberhard. 1988. Pendidikan Kejuruan. Jakarta; Gramedia.

Sardiman A.M. 1994. Interaksi dan Motivasi Belajar Mengajar. Jakarta; PT. Raja Grafindo Persada.

Slameto. 2003. Belajar dan Faktor Faktor yang Mempengaruhinya. Jakarta; PT.Rineka Cipta.

SMK Negeri 1 Nglegok. 2012. Buku Panduan Prakerin Tahun 2011/2012, Pengantar. Blitar; PDF
S. Margono. 2004. Metodologi Penelitian Pendidikan. Jakarta; PT.Rineka cipta.

Suharsimi Arikunto. 2010. Prosedur Penelitian Suatu pendekatan Praktek. Jakarta; PT. Rineka Cipta

Syaiful Bahri Djamarah. 2002. Psikologi Belajar. Jakarta; PT. Rineka Cipta.

Wakhinuddin . 2009.Penerapan PSG Melalui Praktek Kerja Industri pada SMK, (online), (http://wakhinuddin.wordpress. com/2009/07/09/penerapanpsg-melalui-praktek-kerjaindustri-pada-smk/, diakses mare 2012 